\title{
农村公共卫生服务体系建设研究
}

\author{
刘程诚 \\ 黑龙江农业职业技术学院 \\ DOI:10.32629/er.v2i12.2323
}

[摘 要] 农村公共卫生体系的建设,是我国全民公共卫生体系建设的重要组成部分,也是建设社会主义新农村不可或缺的内容。文章分析了公 共卫生服务的状况及其存在的问题,探讨了完善农村公共卫生服务体系建设的具体措施。

[关键词] 农村; 公共卫生; 服务

我国农村的公共卫生体系是由县级公共卫生机构以及乡镇卫生服务 中心和村社区卫生服务站从事防保工作的人员组成, 它是我国农村疾病防 控的第一道屏障。在大量农村人口向城市流动的今天, 如果此屏障不能够 有效发挥作用或是出现漏洞, 将会对社会的公共安全形成威胁, 甚至带来 灾难性的危害。

\section{1 农村公共卫生服务体系的建设现状}

1. 1 政府财政支持不够

在一定程度上影响了农村卫生事业的建设发展一方面是医疗卫生设 施落后一些乡镇卫生服务中心因为缺乏财政支持医疗设备缺乏和老化问 题非常严重另一方面是农村卫生服务工作人员的工资待遇得不到保证导 致农村医疗卫生服务质量越来越低。

\section{2 人才的缺乏}

从整体上来说农村公共卫生服务工作人员队伍的数量不足队伍凝聚 力不强从人员结构上而言乡镇卫生服务中心一般是以中专毕业的人员为 主缺少专业能力强学业层次高的卫生服务人员。

\section{3 突发事件应急储备物资不足}

我国许多县级市财政困难, 无法完全按照国家卫生部应急物资储备要 求对应急物资储备实行动态管理, 疾病预防控制中心只能从有限的经费中 划拨部分资金购买, 一些基本防护装备, 防护药品, 针对大面积突发性公共 卫生事件的防治药品和防护服的储备数量不足。

1.4 农村公共卫生服务的条件相对较差

比如说卫生室设备设施简陃可提供的服务较少而且很多都是乡村医 生联办或者自办的又比如说大部分农村医疗卫生服务人员的待遇较少工 作积极性较低处于被动服务的状态加之我国经济发展水平总体不高用在 农村环境改善农民群众生活安全保障的投入较少。第四农村公共卫生服务 机构组织不完善管理上存在问题自从我国农村实施家庭联产承包责任制 之后, 村级的卫生单位很多都转化成为个体诊所, 这样一来很多的诊所就 将经营的重点放在基本医疗服务上。

1.5 县、乡、村三级公共卫生服务体系关系松散

由于管理体制不顺和市场因素介入等原因, 县级医疗卫生机构在三级 卫生服务网中的 “龙头” 作用减弱。乡镇卫生机构目前普遍存在缺少财政 支持、缺乏业务管理能力和非专业人员安排过多等弊病, 没有起到 “三级 预防保健网的枢纽作用。” 公共卫生服务工作则仍处于重治轻防、以医养 防的囬尬境地, 偏离了卫生工作 “预防为主” 方针的轨道。勉强维持或基 本散了架的 $2 / 3$ 卫生院, 大多卫生技术人才流失, 业务用房破旧, 设备简陃, 公共卫生服务人员安排不足或素质低下, 医疗业务收入杯水车薪, 入不敷 出。公共卫生服务项目、传染病防控等公益性工作则疏于管理, 卫生院失 去了应有的作用。县级公共卫生机构大多财政投入不到位, 定额、业务经 费严重不足, 科室设置不全, 设备落后, 热衷于有偿服务, 没有起到公共卫
生服务技术指导中心应有的作用。

\section{2 巩固农村公共卫生服务体系建设的探索}

2.1 农村公共卫生体系的建设关键还是需要人才

农村公共卫生服务人员的培养必须以农村卫生服务改革目标相符合 必须要以居民卫生服务需求为指导针对农村公共卫生服务人员专业能力 低、高精尖技术人才少的问题, 我们可以从下面几点入手: 首先积极组织培 训教育, 对乡镇公共卫生服务人才展开各种形式的培训和教育, 鼓励一些 有条件和潜力的乡村医生接受学历教育从而提升农村公共卫生服务的质 量其次应该定向培养人才国家有关部门可以设置专门的资金来委托高校 为农村公共卫生事业培养专门的人才学生毕业之后直接分配到乡镇的公 共卫生服务机构参与工作最后应该积极鼓励城市卫生机构的在职或者退 休人员到农村进行公共卫生服务。

2. 2 进一步加强农村医疗卫生建设, 提高医疗技术服务水平

第一, 加强医疗质量建设, 规范医疗秩序。乡镇卫生服务中心要加强医疗 能力建设, 不断提高全科医疗水平。其次, 加强医疗卫生行风建设, 抓好医德 医风, 增强医务人员的服务意识和职业自律意识。医务人员加强职业道德教 育, 树立以病人为中心的服务理念。加强对村医疗管理, 发挥最基层医疗网点 方便群众就医的积极作用。最后, 深化医疗卫生管理体制改革。要遵循政府 主导、社会参与、转换机制和加强监管的原则, 从解决群众反映最强烈的突 出问题入手, 深化医疗卫生管理体制改革, 完善医疗机构运行机制, 强化公共 服务职能, 规范服务行为。要推进乡镇 (中心) 卫生院改革, 合理配置资源, 改 进服务模式, 形成有生机和活力的用人机制和分配激励机制, 提高效率。加强 村级卫生社区服务网络建设, 担负常见病初诊及预防保健任务。发挥社会个 人举办的医疗机构作用, 完善乡村卫生服务管理一体化, 提高整体效能。

2.3强化政府责任, 加大财政对农民

公共卫生体系的投入, 是加强农村公共卫生体系建设的根本保证。政 府对农民的健康保障负有不可推卸的责任。但是, 现实中由于各级政府财 力不足, 严重制约了政府作用的有效发挥。目前, 乡、村两级政府和组织负 债严重几乎成为一个全国性的问题。许多县政府对乡镇卫生组织的防保经 费补助都不能保证。为了保证农村卫生机构工作的正常运行, 保证农民能 够获得公平的、合格的公共卫生和基本医疗服务, 必须改革和完善农村卫 生管理体制和投入机制, 建立和完善规范的财政转移支付制度。在县、乡 政府对农村卫生投入不足的情况下, 中央和省政府有责任针对不同项目实 施农村卫生的专项转移支付。开放政策以来的我国农村公共卫生服务体系 建设, 虽然有党中央、国务院 “卫生事业财政投入的增长速度不低于政府 财政支出的增长速度”的目标要求, 但由于地方政府财力不足, 又没有公共 政策和相关法律的强制支持, 使地方政府对农村公共卫生服务体系建设的 投入不到位, 农村公共卫生体系建设陷入了 “无米之炊” 的境地, 失去了健 康发展的基本条件。要改变农村公共卫生体系这种被动局面, 落实政府筹 


\title{
和谐班级文化促幼儿成长
}

\author{
宁秀娟
}

山东理工小博士幼儿园

DOI:10.32629/er.v2i12.2286

[ 摘 要] 班级文化是一个班级的灵魂, 是师生共同创造的精神财富, 它具有一种无形但强大的教育力量,是塑造心灵、规范行为、重陶人格的重 要平台,班级文化直接影响着幼儿在班级的生活质量、个性发展和知识水平。“集体是教育的工具”,有怎样的班集体文化就会培育出怎样的孩 子。努力建设班级文化,让幼儿在和谐的班级文化中快乐成长,是我们共同的教育目标。

[关键词] 和谐; 班级文化; 幼儿; 成长

\section{1 师幼情感交融,形成班级 “心态文化” 风尚}

1. 1 提出 “真诚和谐、勤奋上进、乐教创新” 的口号。老师彼此取长 补短, 相互配合, 班长身先士卒, 发挥带头作用; 配班老师积极为班级出谋 划策, 保育员做工作的坚强后盾和 “第三只眼睛”, 以微笑、爱心、耐心, 让幼儿真正感受到我们的热情关爱。

1.2 尊重幼儿, 建立平等的师幼关系。弗莱雷认为, 我们的教育不是谁 教育谁, 也不是自己教育自己, 而是通过世界来相互学习, 这种教育是平等 的, 他的关于 “平等、爱、谦逊及信任” 的教学理念告诉我们: 师幼之间 应是一种人格平等的关系, 教师要尊重幼儿, 信任、热爱幼儿, 在与幼儿平 等交流中以智慧、情感启迪。“当孩子把老师当成自己的朋友时, 说明你的 教育就成功了”, 只有孩子把老师当成了朋友, 才不会产生畏惧心理 ${ }^{[1]}$ 。

\section{2 建构自主管理策略,引领班级 “制度文化” 方向}

2. 1 自助活动, 萌发自我管理意识。开展 “我是班级管理员” 活动: 营 造宽松、愉悦的家庭式环境, 让孩子在开放的环境中生活实践。为了让孩 子自我服务、自我管理成为发自内心的行动, 有效开展值日生、小组长、 区域管理员工作。

2. 2 班级特色奖励活动: 自主管理, 提高自我管理能力。尊重幼儿不断 增长的独立需要, 以 “旁观者” 的身份, 把班级管理的执行权交给孩子, 在 讨论、勘䣱、思考、决定的过程中, 幼儿自主制定规则, 与时俱进, 和孩子 们共同创设出激励孩子的 “奖品”, 在班级实施 “特色奖励” 活动, 促进孩 子常规的培养, 引领班级 “制度文化” 方向。

2. 3听故事, 培养幼儿课堂倾听习惯。通过观察发现有不少幼儿在集体 活动中乐意发言, 但却不能安静地倾听同伴或老师说的话; 看电视、听故 事的时候不能安静地看或听, 常常会说一些与当前无关的话题, 缺乏良好

资职能, 加大财政对农村公共卫生体系建设的投入, 是加强农村公共卫生 体系建设的根本保证。

\section{4 健全农村公共卫生服务网络}

首先, 建立完善规范的乡镇公共卫生机构设置。将现有乡镇公共卫生 工作机构 (防保站、防疫股) 统一更名为“XX乡镇公共卫生服务管理办公室”, 简称 “公卫办”, 直接隶属当地政府, 业务隶属卫生局。其次, 公卫办人员 按辖区人口 1 万 2 人/万比例配制, 原则上不少于 6 人, 应当具备医学中专及 以上学历、初级及以上卫生专业技术职称或执业助理医师及以上资格, 现 有从事卫生防疫和妇幼保健工作的人员优先使用。最后, 公卫办根据因事 设岗、因岗定人的原则, 分别明确从事卫生防疫、妇幼保健和卫生监督工 作的专职人员, 爱国卫生与健康教育工作指定相关人员兼职负责。负责卫 生监督工作的专职人员符合卫生监督员条件的, 由区卫生监督所聘为兼职 卫生监督员。
的倾听习惯。老师就利用晨间谈话、餐前餐后、午睡前、离园前后等时间 引导幼儿安静地反复倾听故事, 隔一段时间请幼儿来讲述故事, 渐渐地, 幼 儿对听故事、讲故事活动越来越感兴趣了, 家长反映, 孩子在家也能安静地 听录音机里的故事。在培养倾听习惯的同时, 我们也注重在各项活动中培 养幼儿乐意与同伴交流, 大胆发言的好习惯。在故事中, 小朋友认识了许多 守纪、礼貌、文明的好孩子, 小朋友也渐渐在行动上和他们靠拢, 成为守纪、 大方的孩子 ${ }^{[2]}$ 。

\section{3 大胆创新改良,促进班级 “物态文化” 建设}

3. 1 突出环境的 “教育、互动、创意” 的理念, 从细节着手, 挖掘有价 值的内容, 把 “主题墙” 与 “互动展示” 巧妙整合。将班级每一角落精致 化, 特色化, 让孩子 “一见钟情”, 让环境真正成为孩子们心智成长的精神 家园, 快乐学习的美好地方。

3. 2 创新思维, 重视对课程的解读和反思, 在“预设”中体现匠心, 在“生 成” 中展现智慧, 促进有效互动, 不断优化课程。

(1) 在主题活动开展前, 向幼儿发放各种调查表, 请幼儿回家和父母一 起完成, 这样以来, 不但了解了幼儿的知识经验, 而且还让家长参与到我们 的活动中来, 更好的支持配合我们的工作。如: “了不起的我” 主题活动一 - “妈妈的小帮手” 调查表; “快乐的节日” 主题活动—— “我的六个一” 调查表。

(2) 关注已有经验, 灵活把握方向。关注发展需求, 扩展学习经验。活 动中引导孩子积极、主动地探究环境、操作材料, 敏锐地捕捉孩子们稍纵 即逝的思维火花, 进行有效的呼应及挖掘。

(3) 关注主动发展, 优化活动细节。注意所提供材料的层次性, 尊重幼儿 原有基础, 让每个孩子都有 “跳一跳摘到苹果” 的机会, 在平实中演绎精彩。

\section{3 结语}

总之, 公共卫生服务体系是一个整体的、系统化的体系, 在加强公共卫 生服务体系建设的过程中, 要树立全局意识, 避免各自为政, 不利于整体工 作的推进。具体来说, 就是要从整体着眼对公共卫生服务体系进行规划, 对于基本公共卫生服务项目的实施从整体着眼, 调动各个部门进行分工协 作, 形成整体性的运作机制。

\section{[参考文献]}

[1]孙凯. 基于游客感知的乡村旅游公共卫生服务质量评价研究 [D]. 西 北大学,2018(01):74.

[2]宋桂杭。甘肃省三县基层医疗卫生机构国家基本公共卫生服务均 等化项目效率评价研究[D].兰州大学,2014(10):63.

[3]史园园. 乡镇卫生院服务能力影响因素研究 [D]. 北京协和医学 院,2013(S2):96. 